\title{
POLSZCZYZNA UCZNIÓW ARABSKIEGO POCHODZENIA - STUDIUM PORÓWNAWCZE
}

Słowa kluczowe: język polski jako drugi, polszczyzna edukacyjna, egzamin maturalny, tekst

Streszczenie: Celem niniejszego artykułu jest studium porównawcze polszczyzny uczniów arabskiego pochodzenia, którzy uczęszczają do jednego z łódzkich liceów. Porównania dokonano z dwóch perspektyw - nauczyciela języka polskiego jako rodzimego oraz glottodydaktyka-językoznawcy. W tym celu wykorzystano wypracowania typu maturalnego pisane przez uczniów w trakcie lekcji języka polskiego, do których oceny wykorzystano kryteria maturalne (obowiązujące w formule od roku 2015). Wyniki te osadzono w szerszej perspektywie językoznawczej, uwzględniając znajomość poszczególnych podsystemów języka. Jednakże to właśnie ocena maturalna polszczyzny uczniów wydaje się kluczowa, ponieważ egzamin maturalny (a nie egzamin z języka polskiego jako obcego) stanowi cel dla uczniów.

\section{WSTĘP}

Od kilku lat coraz wyraźniej przecieraną ścieżką glottodydaktyki polonistycznej staje szeroko rozumiane nauczanie języka polskiego jako drugiego ${ }^{1}$, choć jak zauważa P. Gębal ,termin język polski jako drugi wciąż nie jest określeniem zbyt często stosowanym, także wśród samych glottodydaktyków polonistycznych. W znacznej części debat oraz w samym nazewnictwie działań akademickich, takich jak kształcenie nauczycieli, spotkać wciąż można jeszcze

*mateusz.gaze@uni.lodz.pl, Uniwersytet Łódzki, Wydział Filologiczny, Zakład Lingwistyki Stosowanej i Kulturowej, Instytut Filologii Polskiej i Logopedii, ul. Pomorska 171/173, 90-236 Łódź.

${ }^{1}$ Terminu język polski jako drugi używam w odniesieniu do polszczyzny „dzieci imigrantów i uciekinierów politycznych oraz dzieci należących do mniejszości narodowościowych, używających w środowisku rodzinnym języka innego niż polskiego" (Miodunka 2-10, s. 233). 
stosowanie określenia język polski jako obcy także dla realizacji zadań glottodydaktycznych z uczniami z doświadczeniem migracyjnym" (Gębal 2017, s. 176). Nasilające się zjawisko migracji na terenie Unii Europejskiej powoduje, że i w polskich szkołach przybywa uczniów z doświadczeniem migracji. A. Szulgan wyróżnia sześć grup takich uczniów: 1. Dzieci uchodźców i osób starających się o status uchodźcy. 2. Dzieci imigrantów o różnym statusie (pracownicy sezonowi, osoby korzystające z pobytu tolerowanego, osoby korzystające z ochrony czasowej, imigranci nielegalni, inni). 3. Dzieci pracowników migrujących z krajów Unii Europejskich. 4. Dzieci z mniejszości narodowych, zwłaszcza romskiej. 5. Dzieci repatriantów. 6. Dzieci z małżeństw mieszanych (Szulgan 2019, s. 55). Celem niniejszego artykułu jest porównawcze studium przypadku dwojga uczniów arabskiego pochodzenia. Opisu i oceny polszczyzny edukacyjnej uczniów dokonano przede wszystkim z punktu widzenia nauczyciela języka polskiego jako rodzimego ${ }^{2}$, uwzględniwszy oczywiście perspektywę glottodydaktyczną, która jest dobrze znana autorowi artykułu. Spojrzenie takie ma wymiar pragmatyczny - wydaje się, że jednym z najistotniejszych celów uczniów w liceum jest jak najlepsze zdanie egzaminu maturalnego, którego wynik decyduje o przyjęciu na studia. Proces dydaktyczny w szkole ponadpodstawowej jest zatem ukierunkowany na egzamin maturalny. Uczniowie już od pierwszej klasy oswajają się z formułą egzaminu, by wypaść na nim jak najlepiej. Choć matura jest egzaminem nieobowiązkowym, to jednak niewielu absolwentów liceów do niej nie podchodzi. Wśród przyszłych abiturientów znajdują się również uczniowie, dla których polszczyzna nie jest językiem rodzimym.

\section{CHARAKTERYSTYKA UCZESTNIKÓW BADANIA}

Opisowi poddano polszczyznę dwojga uczniów arabskiego pochodzenia - chłopca i dziewczyny. Uczennica urodziła się w 2004 roku w Łodzi, rodzice to Algierczycy (definiujący swoją przynależność do ludności berberyjskiej), którzy przyjechali do Polski w 2002 roku. Ojciec posługuje się płynnie językiem polskim (ukończył studia w języku polskim). Matka słabo mówi po polsku (rozumie codzienną komunikację). W domu językiem komunikacji jest arabski, niekiedy francuski, rzadko polski (ostatnio częściej dzięki nauczaniu zdalnemu oraz rozwojowi córek). Uczennica chodziła do międzynarodowego przedszkola, jednak edukację obowiązkową odbywała w polskich placówkach publicznych (szkoła podstawowa, liceum). Egzamin ósmoklasisty zdała bez dostosowań dla dzieci

${ }^{2}$ Do tego celu wykorzystano wypracowania typu maturalnego pisane na lekcjach językach polskiego. Oceny dokonano, opierając się na kryteriach maturalnych stosowanych podczas oceny prac z języka polskiego na poziomie podstawowym. 
niepolskiego pochodzenia ${ }^{3}$ (poza dostosowaniami zaleconymi przez poradnię psychologiczno-pedagogiczną ${ }^{4}$. Uczennica uzyskała lepszy wynik z egzaminu z matematyki niż z języka polskiego. W roku szkolnym 2020/2021 uczennica chodziła do klasy II LO (do klasy o profilu chemicznym i nauk o życiu - z podstawowym poziomem nauczania języka polskiego).

Uczeń urodził się w 2005 roku w Iraku, matka jest Polką, a ojciec Irakijczykiem, który przyjechał w latach 90. do Polski, a później wrócił (z małżonką) do Iraku. Ojciec zna język polski na poziomie komunikatywnym ${ }^{5}$. W domu językiem komunikacji jest przede wszystkim polski, następnie arabski (w kontaktach z ojcem i rodziną ojca). Uczeń do szóstego roku życia wychowywany był w dwóch krajach - Iraku i Polsce. Edukacja obowiązkowa w całości odbywała się w polskich placówkach publicznych (szkoła podstawowa, liceum). Egzamin ósmoklasisty został zdany bez dostosowań dla dzieci niepolskiego pochodzenia (poza dostosowaniami zaleconymi przez poradnię psychologiczno-pedagogiczną ${ }^{6}$ ). Uczeń uzyskał lepszy wynik z egzaminu z języka polskiego niż z matematyki. W roku szkolnym 2020/2021 uczeń chodził do klasy I LO (do klasy o profilu społecznym $-\mathrm{z}$ rozszerzonym poziomem nauczania języka polskiego).

Już ta krótka charakterystyka mogłaby prowadzić do postawienia tezy, że poziom językowy ucznia będzie wyższy niż uczennicy. Uczennica pochodzi z rodziny niepolskiej i z językiem polskim w pierwszych latach życia miała sporadyczny kontakt (rodzice wskazali plac zabaw oraz przedszkole jako główne miejsca kontaktu z polszczyzną). Uczennica też na egzaminie ósmoklasisty uzyskała słabszy wynik z języka polskiego niż z matematyki, a w liceum realizuje język polski w zakresie podstawowym. Uczeń natomiast ma matkę Polkę, od urodzenia polski był obecny w domu, co więcej, według ucznia polszczyzna jest od wielu lat głównym językiem komunikacji w domu. Uczeń uzyskał lepszy wynik z języka polskiego niż z matematyki, a w liceum realizuje język polski w zakresie rozszerzonym.

\footnotetext{
${ }^{3}$ Egzamin ósmoklasisty jest egzaminem obowiązkowym dla uczniów, dlatego też dla cudzoziemców, którym „ograniczona znajomość języka polskiego utrudnia zrozumienie czytanego tekstu” (takie sformułowania pojawiają się w Komunikatach dyrektora Centralnej Komisji Egzaminacyjnej w sprawie szczegółowych sposobów dostosowania warunków i form przeprowadzania egzaminu ósmoklasisty od 2018 roku) przygotowywane są ,odrębne arkusze dostosowane do potrzeb i możliwości zdających".

${ }^{4} \mathrm{U}$ uczennicy zdiagnozowano specyficzne trudności w czytaniu i pisaniu w zakresie dysleksji i dysortografii. Dzięki opinii uczennica miała wydłużony czas egzaminu i dostosowane kryteria oceniania $z$ języka polskiego i języka obcego. W praktyce egzaminacyjnej oznacza to inne kryteria oceniania (zwykle łagodniejsze) w zakresie ortografii i interpunkcji.

${ }^{5}$ Tak określili poziom polszczyzny uczeń (syn) i jego matka. Nie zaistniała możliwość zweryfikowania tego stwierdzenia.

${ }^{6} \mathrm{U}$ ucznia również zdiagnozowano specyficzne trudności w czytaniu i pisaniu w zakresie dysleksji, dysortografii i dysgrafii. Dzięki opinii uczeń również miał wydłużony czas pisania egzaminu i dostosowane kryteria oceniania egzaminu z języka polskiego i języka obcego.
} 


\section{STATUS POLSZCZYZNY}

U uczennicy język polski w pierwszych latach życia występował sporadycznie (do 4 roku życia był to język obcy), od przedszkola polszczyzna pojawiała się już częściej, choć dopiero w szkole podstawowej można określić jej status jako języka drugiego. Obecnie język polski stał się językiem dominującym, ponieważ jest językiem edukacji, dzięki czemu uzyskał status języka funkcjonalnie pierwszego.

U ucznia od urodzenia język polski traktowany był na równi z językiem arabskim (były to języki rodzime obojga rodziców), obecnie jest językiem dominującym, ponieważ jest językiem edukacji oraz językiem częściej używanym w domu, dzięki czemu uzyskał status języka funkcjonalnie pierwszego.

\section{DODATKOWE GODZINY JEZZYKA POLSKIEGO}

Zarówno dzieci cudzoziemców, jak i dzieci obywateli polskich powracających z zagranicy mają prawo do dodatkowej nauki języka polskiego w wymiarze 2 godzin tygodniowo oraz do dodatkowych zajęć wyrównawczych z nauczanych przedmiotów przez okres nieprzekraczający 12 miesięcy. Łączny wymiar zajęć i godzin języka polskiego nie może przekroczyć 5 godzin tygodniowo ${ }^{7}$. Co ciekawe, tylko uczennica wyraziła chęć uczestniczenia w takich zajęciach - przez rok miała 2 godziny tygodniowo języka polskiego z polonistą z przygotowaniem glottodydaktycznym. Uczeń nie wyraził chęci uczestniczenia w takich zajęciach - argumentem miała być zbyt duża liczba zajęć szkolnych i pozaszkolnych.

\section{BADANY MATERIAL}

Podstawę analizy stanowiły teksty prac stylistycznych (głównie rozprawek typu maturalnego) pisanych na lekcji. W przypadku ucznia uwzględniono również prace pisane $\mathrm{w}$ domu, ponieważ już pierwsze wypracowania ucznia pokazały, że ma on bardzo duże problemy z pisaną odmianą polszczyzny. Nie uwzględniano interpretacji utworów poetyckich, ponieważ uczniowie rzadko wybierają tę formę na egzaminie maturalnym, więc na lekcjach polskiego ćwiczona jest głównie w formie pisemnej rozprawka typu maturalnego. Jest to również gatunek, któ-

\footnotetext{
${ }^{7}$ Kwestie funkcjonowania uczniów z doświadczeniem migracji w polskich szkołach reguluje dość dokładnie Rozporządzenie Ministra Edukacji Narodowej z dn. 23 sierpnia 2017 r. w sprawie kształcenia osób niebędących obywatelami polskimi oraz osób będących obywatelami polskimi, które pobieraty naukę $w$ szkotach funkcjonujących w systemach oświaty innych państw.
} 
ry uczniowie (choć w części) poznają w szkole podstawowej ${ }^{8}$. Analizie poddano również ustne wypowiedzi uczniów, które zarejestrowano w trakcie rozmów ze mną, nauczycielem języka polskiego (były to więc wypowiedzi w odmianie oficjalnej). Przeprowadzono również wywiady z rodzicami uczniów. Rozmawiałem przede wszystkim z ojcem uczennicy, rozmowy z jej matką były dość lapidarne, co spowodowane było słabą znajomością polszczyzny. W przypadku ucznia przeprowadzano rozmowy jedynie z matką ucznia. Rozmowy te pozwoliły przede wszystkim na uzyskanie informacji o rozwoju językowym dzieci i przebiegu ich edukacji (nie tylko językowej). Przeprowadzono również rozmowy z ośmiorgiem nauczycieli uczniów ${ }^{9}$, które pozwoliły stwierdzić, że u obojga nauczyciele przedmiotów zauważają braki w kompetencji językowej. Wszyscy nauczyciele zwracali szczególną uwagę na błędy leksykalne i gramatyczne.

\section{KRYTERIA OCENY}

W związku z tym, że dla żadnego z uczniów polszczyzna od wielu lat nie jest językiem obcym, nie zdecydowano się na zastosowanie kryteriów właściwych dla egzaminów z języka polskiego jako obcego. Uczniowie ci są obywatelami Polski, więc prawdopodobnie nie będą też oni nigdy zdawać egzaminu certyfikatowego z języka polskiego jako obcego. Jako szkołę ponadpodstawową wybrali oni liceum ogólnokształcące, co wskazuje ${ }^{10}$, że planują oni iść później na studia. Brakuje narzędzi do diagnozy poziomu językowego uczniów z doświadczeniem migracji ${ }^{11}$. Dlatego też zdecydowano się, że kryterium oceny poziomu polszczyzny uczniów będą kryteria maturalne właściwe egzaminowi z języka polskiego na poziomie podstawowym. Według tych kryteriów prace wszystkich uczniów w liceum oceniane są już od pierwszego semestru pierwszej klasy ${ }^{12}$. Będzie to też narzędzie, którym oceniane są prace wszystkich abiturientów, którzy decydują się zdawać egzamin maturalny ${ }^{13}$.

\footnotetext{
${ }^{8} \mathrm{Na}$ egzaminie ósmoklasisty uczeń ma do wyboru napisać wypracowanie o charakterze argumentacyjnym lub wypracowanie o charakterze twórczym (opowiadanie).

${ }^{9} \mathrm{~W}$ przypadku uczennicy rozmawiano z nauczycielami: biologii, chemii, matematyki i historii, a w przypadku ucznia z nauczycielami: historii, wiedzy o społeczeństwie, geografii i biologii.

${ }^{10}$ Potwierdzają to również rozmowy z uczniami i ich rodzicami.

${ }^{11}$ Obecnie powstają takie programy nauczania z testami, jednak dedykowane są one uczniom dużo młodszym (Bernacka-Langier A., Dąbrowa E., Pawlic-Rafałowska E., Wasilewska-Łaszczuk J., Zasuńska M. 2011; Pamuła-Behrens M., Szymańska M. 2017).

${ }^{12}$ Regulują to przedmiotowe zasady oceniania z języka polskiego, w myśl których przy ocenianiu wypracowań stosuje się właściwe kryteria maturalne na poziomie podstawowym lub rozszerzonym.

${ }^{13} \mathrm{~W}$ przypadku egzaminu maturalnego nie ma możliwości dostosowania arkusza dla potrzeb cudzoziemców. Jest to przede wszystkim spowodowane tym, że egzamin maturalny (w przeciwieństwie do egzaminu ósmoklasisty) nie jest egzaminem obowiązkowym.
} 
Jak podaje Informator maturalny rozprawka na poziomie podstawowym jest formą wypowiedzi pisemnej na podany temat, która wymaga od zdającego:

- zrozumienia załączonego do polecenia tekstu literackiego (epickiego lub dramatycznego);

- sformułowania własnego stanowiska (tezy lub hipotezy) wobec problemu postawionego w poleceniu i odnoszącego się do zamieszczonego w arkuszu tekstu literackiego;

- rzeczowego uzasadnienia swojego stanowiska;

- odwołania się do załączonego tekstu oraz do wybranego tekstu / wybranych tekstów kultury. W przypadku, jeśli dany tekst literacki jest fragmentem lektury oznaczonej w podstawie jako obowiązkowa, uczeń powinien także odwołać się do całości utworu. Szczegółowe wskazówki dotyczące liczby tekstów i sposobu odwołania się do nich znajdują się w poleceniu;

- napisania wypowiedzi, którą powinien cechować widoczny zamysł kompozycyjny, wyrażający się w funkcjonalnej segmentacji i uporządkowaniu tekstu stosownie do wskazanego gatunku wypowiedzi.

Wypracowanie nie może liczyć mniej niż 250 słów.

(Informator o egzaminie maturalnym z języka polskiego od roku szkolnego 2014/2015, s. 17)

Rozprawka oceniana jest w ośmiu kategoriach, za które łącznie można zdobyć 50 pkt. Ważne jest jednak, że jeśli w kategorii A lub B praca zostanie oceniona na 0 punktów, egzaminator nie przyznaje punktów w pozostałych kategoriach. Jeśli uczeń napisze pracę krótszą niż 250 słów, egzaminator przyznaje punkty tylko w kategoriach: A, B, C (nie może przyznać 22 punktów za kategorie D-H) (Informator ..., s. 140). By zdać egzamin maturalny, należy uzyskać $30 \%{ }^{14}$. Natomiast zgodnie z przedmiotowymi zasadami oceniania w PLOUŁ pracę ocenia się pozytywnie, jeśli uzyska 50\% wymaganych punktów.

${ }^{14}$ Jest to $30 \%$ liczone łącznie za wypracowanie (50pkt.) i test rozumienia tekstu (20 pkt.). 


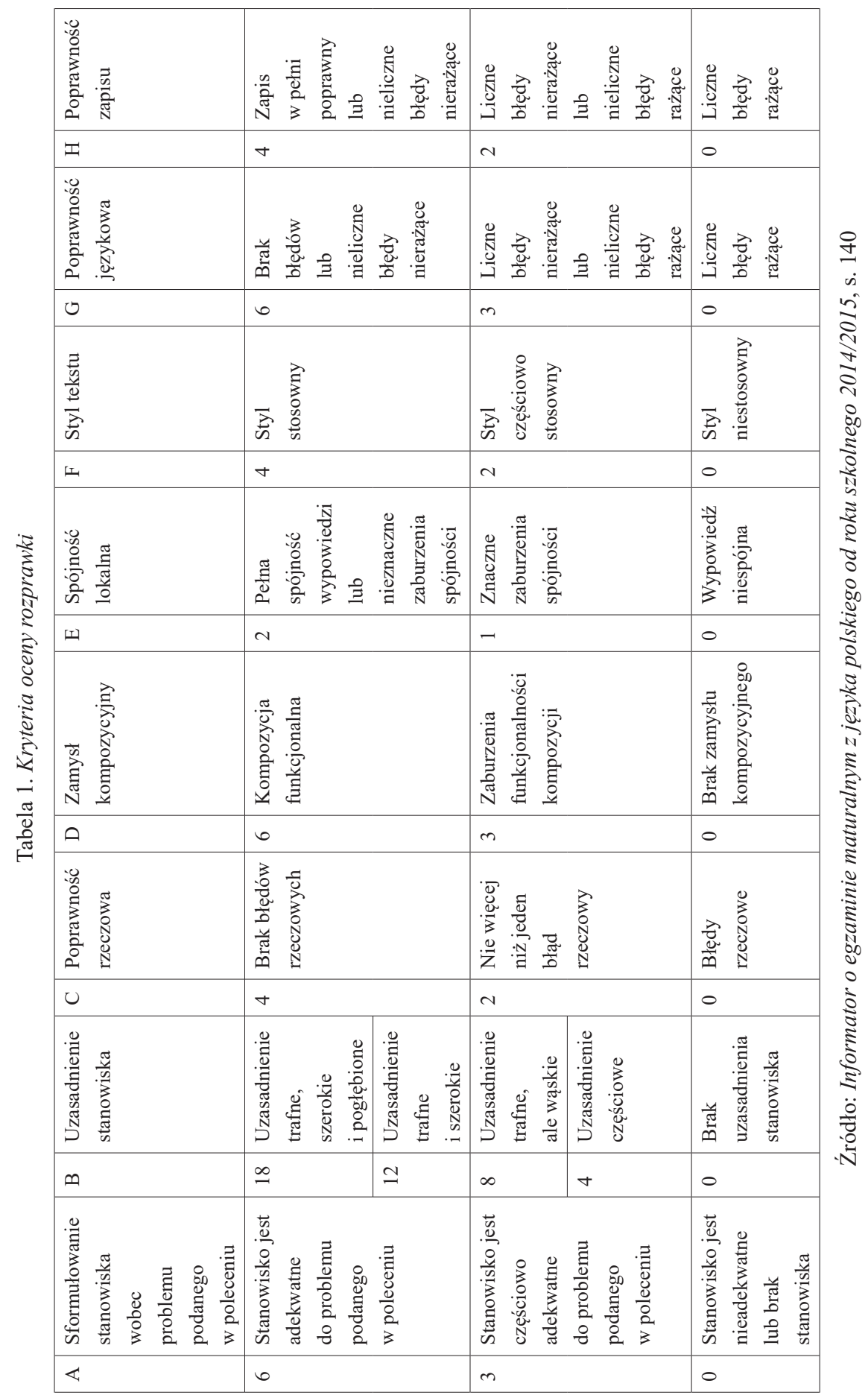




\section{OCENA SZKOLNA PRAC (OCENA NAUCZYCIELA JEZZYKA POLSKIEGO JAKO RODZIMEGO)}

W przypadku uczennicy ocenie poddano 6 rozprawek napisanych w klasie I i 3 rozprawki napisane w klasie II do marca 2021 roku. Pierwsze dwie prace oceniono w przedziale 50-59\% (A3, B8 lub 12, C2, D3, E1, F0 lub 2, G0, H2). Kolejne dwie oceniono w przedziale 60-70\% (A6, B8 lub12, C2 lub 4, D3 lub 6, $\mathrm{E} 2, \mathrm{~F} 2$ lub 4, G0, H2). Ostatnie dwie prace pisane w I klasie ${ }^{15}$ oceniono w przedziale 71-80\% (A6, B12, C2 lub 4, D6, E2, F2 lub 4, G0, H2). Prace pisane w klasie II zwykle były oceniane w przedziale 60-75\% (A3 lub 6, B8 lub 12, C2 lub 4, D3 lub 6, E2, F2 lub 4, G0, H2). Warto zaznaczyć, że najdłuższa praca liczyła 494 słowa.

Uczennica bardzo szybko przyswoiła nową formę gatunkową i dostosowała do niej swoje dotychczasowe umiejętności (argumentowania i przywoływania w odpowiedni sposób przykładu). Kompozycja prac jest właściwa i funkcjonalna. Problem stanowi jedynie graficzne rozmieszczenie tekstu ${ }^{16}$. Występują nieznaczne zaburzenia spójności wewnątrzakapitowej (międzyzdaniowej). Styl prac jest stosowny (błędy, które się pojawiają, wynikają z nadużywania form osobowych i sporadycznie występujących potocyzmów). Niepokojące są liczne rażące błędy językowe - w ostatnich pracach jest średnio 15-18 błędów gramatycznych. Choć w zapisie zauważono liczne rażące błędy ortograficzne i interpunkcyjne, to przyznawano uczennicy 2 pkt. za zapis, ponieważ posiada ona opinię o dysortografii z poradni psychologiczno-pedagogicznej. Niższe wyniki za komponenty A i B uzyskiwane w klasie II są spowodowane trudniejszym materiałem literackim, z którym musiała zmierzyć się uczennica ${ }^{17}$. Ponadto prace analizowane i korygowane były na dodatkowych lekcjach z języka polskiego. Pozostawałem w stałym kontakcie z drugą polonistką, co pozwoliło na bieżącą pracę nad pojawiającymi się problemami w pracach uczennicy.

W przypadku ucznia sprawdzono 6 prac w klasie I do marca 2021 roku $^{18}$. Pierwsze dwie prace oceniono w przedziale 15-25\% (A3, B4 lub 8, C0 lub 2, D0, E0, F0, G0, H0). Prace były krótsze niż 250 słów, co uniemożliwiło przyznanie punktów w kategoriach D-H. Kolejne dwie w przedziale 25-35\% (A3 lub 6, B4 lub 8, C0 lub 2, D3, E1, F0, G0, H2). Ostatnie 2 prace ucznia oceniono w przedziale 40-48\% (A3 lub 6, B8, C0 lub 2, D3, E1, F0 lub 2, G0, H2). Warto zaznaczyć, że najdłuższa praca liczyła 311 słów.

${ }^{15}$ Były to prace pisane w domu ze względu na naukę on-line.

${ }^{16}$ Błędy w tym zakresie wynikają zapewne ze zdiagnozowanej dysleksji rozwojowej.

${ }^{17}$ Klasa I obejmowała teksty stosunkowo krótkie powstałe między starożytnością a barokiem. Klasa II to przede wszystkim duża liczba trudnych dla uczniów tekstów romantycznych i długich tekstów pozytywistycznych.

${ }^{18}$ Uczeń jest o rok młodszy od uczennicy, zatem i materiał badawczy jest uboższy. 
Uczeń ma bardzo duży problem z przyswojeniem nowej formy gatunkowej. Często nie dostrzega różnicy między argumentem i przykładem (wynika to zapewne z nieodpowiednio wykształconych umiejętności w szkole podstawowej). Występują zaburzenia funkcjonalności kompozycji (nieporadny wstęp, często jednozdaniowe podsumowania, brak uogólnień). Zauważono znaczne zaburzenia spójności (głównie wewnątrzakapitowej). Styl prac jest niestosowny lub częściowo stosowny (występuje bardzo duża liczba poetyzmów i archaizmów ${ }^{19}$ ). W każdej pracy odnotowano liczne rażące błędy językowe - średnio 24-26 błędów gramatycznych ${ }^{20}$. Choć w zapisie zauważono liczne rażące błędy ortograficzne i interpunkcyjne, to przyznano uczniowi 2 pkt. za zapis, ponieważ posiada on opinię o dysortografii z poradni psychologiczno-pedagogicznej. Uczeń był niechętny do indywidualnego omówienia prac z polonistą, nie uczęszczał na dodatkowe lekcje języka polskiego, więc analiza błędów popełnionych przez ucznia była powierzchowna. Brakowało też indywidualnej pracy ucznia nad błędami popełnionymi w wypracowaniach.

U obojga ostatnie prace przekraczały $30 \%$ konieczne do zdania egzaminu maturalnego. Uczeń jednak miał problemy z uzyskaniem oceny dopuszczającej, ponieważ kryteria przedmiotowe pozwalają ocenić pracę pozytywnie dopiero powyżej 50\%. Ponadto problemem u ucznia przez długi czas było napisanie tekstu na min. 250 słów. A dopiero przekroczenie tego limitu pozwoliło przyznać punkty za kompozycję, spójność, styl, poprawność językową i poprawność zapisu. Warto jeszcze zaznaczyć, że uczeń zdecydował się realizować materiał z języka polskiego na poziomie rozszerzonym, na którym kryteria oceny prac pisemnych są oczywiście surowsze, a w klasie I i semestrze zimowym klasy II ćwiczone będą formy wypowiedzi typowe dla poziomu podstawowego ${ }^{21}$.

\section{OCENA GLOTTODYDAKTYCZNA I JEZZYKOZNAWCZA (OCENA NAUCZYCIELA JEZZYKA POLSKIEGO JAKO OBCEGO/DRUGIEGO)}

Uczeń mówi swobodnie i płynnie. W wypowiedziach oficjalnych o charakterze ogólnym rzadko daje się zaobserwować błędy gramatyczne i leksykalne. Niechętnie on jednak wypowiada się na tematy specjalistyczne. Uczennica mówi swobodnie, ale płynność wypowiedzi jest zaburzona. Wydaje się, że częste pauzy

${ }^{19}$ Uczeń powiela styl przeczytanych tekstów. Nie umie odróżnić wartości stylistycznej słów, np. gdy pisze o tekście średniowiecznym, nieświadomie powiela archaizmy.

${ }^{20} \mathrm{U}$ uczennicy liczba błędów językowych jest niższa, a pisze ona dużo dłuższe teksty.

${ }^{21}$ Co więcej, by zdać egzamin maturalny należy uzyskać 30\% z egzaminów obowiązkowych, tj. z języka polskiego, matematyki i języka obcego na poziomie podstawowym. Nie ma progu punktowego dla poziomu rozszerzonego. 
wynikają z próby znalezienia odpowiedniego słowa. Uczennica nie boi się wypowiadać na tematy specjalistyczne, chętnie na nie dyskutuje (również w trakcie nauczania online).

Oceniając podsystem fonetyczny, należy zauważyć, że artykulacja głosek i prozodia u ucznia jest na poziomie rodzimego użytkownika polszczyzny. U uczennicy prozodia jest jak u rodzimego użytkownika polszczyzny, stwierdzono jednak nienormatywną realizację wszystkich głosek szeregu szumiącego: [̌̌s], [ž], [č], [̌̌], dwóch głosek szeregu ciszącego: [ć], [3́] i głoski drżącej [r]. Ponadto u uczennicy występuje lekkie nosowanie.

U obojga badanych najwięcej błędów stwierdzono w odniesieniu do podsystemu gramatycznego. Były to zarówno błędy w zakresie składni zgody (zwłaszcza składni podmiotu i orzeczenia oraz przydawek przymiotnych) oraz składni rządu (zarówno tej przyimkowej, jak i bezprzyimkowej). Dużym problemem u obojga jest również składnia zdania wielokrotnie złożonego. Prace ucznia liczą średnio 14 zdań. W większości są to zdania dwuorzeczeniowe. W każdym wypowiedzeniu dłuższym niż 2 orzeczenia pojawiały się błędy składniowe. Tak duża liczba błędów gramatycznych oraz błędów z innych podsystemów może powodować, że teksty przez niego pisane będą w małym stopniu zrozumiałe przez rodzimych użytkowników polszczyzny:

Nieporozumienie możemy znaleźć również $w$ książce Charles Dickensa pod tytułem „Opowieść Wigilijna”. Główny bohater Ebenezer Srooge jest już od wczesnych lat nie umial znaleźć porozumienia z swoim ojcem, co przeniosto się później na jego życie $w$ dorostość. Choć miat rodzinne. nie chcial utrzymywać z nia kontaktu, przez to wiódt samotny tryb życia. przez który nie byt przychylny do innych ludzi, a nawet do swojego siostrzeńca. Kiedy ten go zaprosit na Wigilię, lecz Ebenezer nie przyjąt zaproszeniem. Nawiedzenie Ebenezer przez siedem duchów, które kazały mu się zmienić, inaczej czekataby go śmierć22.

Fragment czwartej rozprawki napisanej przez ucznia

Ludzie nie moga się porozumieć, ze względu na to, że każdy jest indywidualny i każdy decyduje sam o sobie i niektórzy uważaja ,że wiedza więcej i lepiej, i zawsze ma racje bez względu na wszystko. W, Antygonie” Kreon po utracie żony oraz syna dochodzi do wniosku że nie warto było sprowadzić sporu z Hejmonem. Dochodzę do wniosku na podstawie przytoczonych tytułów, że ludzie moga dojść do porozumienia tylko po tragicznym zakończeniu. Tak starałem się wybrać lektury, żeby każdy spór byt rozwiany jakaś tragedia . Życie byto by duże tatwiejsze gdyby ludzie umieli się ze soba dogadać.

Fragment czwartej rozprawki napisanej przez ucznia

Prace uczennicy liczą średnio 21 zdań. Ponad połowa z nich to wypowiedzenia z minimum trzema wypowiedzeniami składowymi (powtarzające się błędy dotyczą imiesłowowych równoważników zdania i zdań wtrąconych).

\footnotetext{
${ }^{22}$ We wszystkich przytoczeniach zachowano oryginalną pisownię.
} 
Nauczyciele przedmiotów zauważali, poza błędami gramatycznymi, błędy leksykalne. I to one według nich są najbardziej niepokojące, ponieważ wpływają również na oceny z nauczanych przedmiotów. Zwrócili oni szczególną uwagę na mylenie słów podobnych znaczeniowo (np. uwalniać a wyzwalać, przenosić a roznosić, wnikać a wchłaniać) czy błędy powstałe przez naruszenie reguł słowotwórczych (np. transportność czy glupość). Problemem (zaobserwowanym również w analizowanych rozprawkach) były błędy w zakresie łączliwości wyrazów, np. petnić rolę, robić życzenia, mieć spór, robić ucieczkę do snu, podnosić tarcie.

Jak już wspomniano, w wypowiedziach uczennicy sporadycznie pojawiają się frazeologizmy z języka potocznego czy poetyzmy. Dużo większy problem ze stylistyką tekstu ma uczeń. Używa on stylu tekstów, które przywołuje, a więc pojawiają się w jego tekstach archaizmy i poetyzmy:

Pierwszym takim przykładem jest Mieszko I, dzięki, któremu światto niebiańskie nawiedziło Królestwo Polskie. Gdy ubogi wieśniak lub kobiecina skarżyła się na któregoś z książat lub komesów, to chociaż byt zajęty ważnymi sprawami, to ruszat wystuchać każdego po kolei wedle stanu.

Co więcej, uczeń nie rozumie, że ich użycie jest błędne, co świadczy o zaburzeniach w określaniu wartości stylistycznej słowa. Uczeń, zwłaszcza w piśmie, słabo rozróżnia style funkcjonalne polszczyzny.

\section{PODSUMOWANIE}

Uczennica, choć wychowana w niepolskiej rodzinie, zdecydowanie lepiej operuje językiem polskim. Jest świadoma swoich błędów, umie je korygować, a co najważniejsze - chce, by jej polszczyzna była na coraz wyższym poziomie. Niestety w pracach pisemnych pojawia się duża liczba błędów gramatycznych, które przez egzaminatorów maturalnych zakwalifikowane będą jako rażące. Niepokojące są również błędy leksykalne, które często są powodem obniżenia oceny z przedmiotów (zwłaszcza z biologii).

Uczeń operuje swobodnie mówioną odmianą języka (ogólną). Jego prozodia i wymowa głosek jest taka jak rodzimych użytkowników polszczyzny. Bardzo duży problem stanowi sprawność pisania. Choć wychowany jest w rodzinie mieszanej i od początku miał stały kontakt z językiem polskim, to jego poziom polszczyzny jest zdecydowanie gorszy. Uczeń wykazuje bardzo niski poziom świadomości językowej w zakresie poprawności stylistycznej, gramatycznej i leksykalnej. Powiela styl przeczytanych tekstów, gdy przywołuje je w pracach pisemnych. Duża liczba różnych błędów może powodować, że teksty przez niego pisane będą niezrozumiałe dla rodzimych użytkowników polszczyzny. 
Dwujęzyczność może być darem, jednak należy o niego odpowiednio zadbać. W przypadku dzieci istotna jest rola rodziców (Cieszyńska 2006). Wydaje się jednak, że w przypadku młodzieży istotne jest już nastawienie młodego człowieka. Uczennica jest świadoma, że musi pracować nad poziomem języka polskiego. Swobodna codzienna komunikacja nie wystarcza, by równie swobodnie operować polszczyzną edukacyjną. Wydaje się, że uczeń takiej świadomości nie ma albo wie, że praca nad doskonaleniem polszczyzny nie jest łatwa i wymaga wysiłku. Powoduje to narastające problemy z operowaniem polszczyzną edukacyjną.

\section{UZUPEENIENIE}

24 marca 2021 r. Centralna Komisja Egzaminacyjna opublikowała nowe wytyczne dla uczniów, którzy będą zdawać egzamin maturalny od maja 2023 roku ${ }^{23}$. Dotyczy to więc również badanych uczniów ${ }^{24}$. Od 2023 r. matura pisemna z języka polskiego składa się z 3 części: języka polskiego w użyciu, testu historycznoliterackiego i pracy stylistycznej. Wymagane będzie napisanie pracy na min. 400 słów $^{25}$. W pracy konieczne będzie odwołanie się do listy lektur obowiązkowych, która liczy 40 pozycji. Zmieniono również kryteria oceny pracy pisemnej (punkty będą przyznawane za „zróżnicowaną składnię”, „zróżnicowaną leksykę, w tym bogatą frazeologię i precyzyjne słownictwo"26). Jeśli egzaminator uzna, że w pracy użyto „wąskiego zakresu środków językowych, tzn. składnia i leksyka są proste/ograniczone", to za 12 błędów językowych będzie musiał przyznać 0 pkt. (na 7 możliwych do zdobycia) ${ }^{27}$.

${ }^{23}$ Informator o egzaminie maturalnym z języka polskiego jako przedmiotu obowiazkowego (część ustna oraz część pisemna na poziomie podstawowym) od roku szkolnego 2022/2023, cke.gov. pl (dostęp: 29.06.2021).

${ }^{24}$ Uczennica planowo powinna podejść do egzaminu maturalnego w maju 2023 roku, uczeń w maju 2024 roku.

${ }^{25}$ Zaznaczę tylko, że najdłuższa praca ucznia liczyła 311 słów.

${ }^{26}$ Do tej pory w kryteriach maturalnych nie oceniano ani bogactwa leksykalnego, ani bogactwa składniowego. Brano pod uwagę jedynie poprawność w zakresie tych podsystemów.

${ }^{27} \mathrm{~W}$ dotychczas obowiązujących kryteriach kierowano się kryterium jakościowym, nie ilościowym. Co więcej, do tej pory za poprawność językową można było uzyskać 6 pkt., co stanowiło $12 \%$ punktów za całą pracę. Od 2023 roku za „zakres i poprawność środków językowych” można uzyskać 7 pkt, co stanowi 20\% punktów za całą pracę (za wypracowanie można będzie uzyskać 35 punktów). 


\title{
BIBLIOGRAFIA
}

Bernacka-Langier A., Dąbrowa E., Pawlic-Rafałowska E., Wasilewska- Łaszczuk J., Zasuńska M., 2011, Praca z uczniem cudzoziemskim. Przewodnik dobrych praktyk dla dyrektorów, nauczycieli, pedagogów i psychologów, Warszawa, www.ore.edu.pl (dostęp: 29.06.2021).

Cieszyńska J., 2006, Dwujęzyczność, dwukulturowość - przekleństwo czy bogactwo? O poszukiwaniu tożsamości Polaków w Austrii, Kraków.

Gębal P.E., 2017, Nauczyciel i nauczanie języka polskiego jako drugiego we wspótczesnej rzeczywistości edukacyjnej, „Kultura-Społeczeństwo-Edukacja”, nr 1 (11), s. 175-192. DOI 10.14746/ kse.2017.11.11

Informator o egzaminie maturalnym z języka polskiego jako przedmiotu obowiąkowego (część ustna oraz część pisemna na poziomie podstawowym) od roku szkolnego 2022/2023, cke.gov.pl (dostęp: 29.06.2021).

Informator o egzaminie maturalnym z języka polskiego od roku szkolnego 2014/2015, cke.gov.pl (dostęp: 29.06.2021).

Komunikaty dyrektora Centralnej Komisji Egzaminacyjnej w sprawie szczegółowych sposobów dostosowania warunków i form przeprowadzania egzaminu ósmoklasisty, https://cke.gov.pl/ egzamin-osmoklasisty/harmonogram-komunikaty-i-informacje/ (dostęp: 29.06.2021).

Miodunka W.T., 2010, Polszczyzna jako język drugi. Definicja języka drugiego, w: J.S. Gruchała, H. Kurek (red.), Silva rerum philologicarum. Studia ofiarowane Profesor Marii Strycharskiej-Brzezinie z okazji Jej jubileuszu, Kraków, s. 233-245.

Rozporzadzenie Ministra Edukacji Narodowej z dn. 23 sierpnia 2017 r. w sprawie kształcenia osób niebędących obywatelami polskimi oraz osób będacych obywatelami polskimi, które pobierały naukę $w$ szkołach funkcjonujacych $w$ systemach oświaty innych państw, http://isap.sejm.gov. pl/isap.nsf/DocDetails.xsp?id=WDU20170001655 (dostęp: 29.06.2021).

Pamuła-Behrens M., Szymańska M., 2017, W polskiej szkole. Materiały do pracy z uczniami z doświadczeniem migracji. Przewodnik, www.fundacjareja.eu (dostęp: 29.06.2021).

Szulgan A., 2019, Praca z dziećmi cudzoziemskimi w polskiej szkole. Metody działania i własne doświadczenia, „Języki Obce w Szkole”, nr 4, s. 55-59.

\section{Mateusz Gaze}

\section{THE POLISH LANGUAGE OF STUDENTS OF ARABIC ORIGIN - COMPARATIVE STUDY}

Keywords: Polish as a second language, Polish as a language of education, matura exam, text

\begin{abstract}
The aim of this article is a comparative study of the Polish language of two students of Arabic origin who attend one of the high schools in Lodz. The comparison was made from two perspectives - from the perspective of the teacher of Polish as a native language and the perspective of the teacher of Polish as a second language. For this purpose, the author used the examination essays written by students during Polish language lessons, for the assessment of which the criteria for the matura exam were used (criteria applicable from 2015). These results were embedded in a linguistic perspective, taking into account the knowledge of language subsystems. However, it is the assessment of the Polish language of students in accordance with the criteria of the matura exam that is important because this exam (not the exam in Polish as a foreign language) is the goal of the students.
\end{abstract}


